Case Report

\title{
Sudden Unexpected Death in a Patient with Tumour Associated Pulmonary Embolism
}

\author{
D. Laohachewin, ${ }^{1}$ F. André, ${ }^{1}$ D. Tschaharganeh, ${ }^{2}$ H. A. Katus, ${ }^{1}$ and G. Korosoglou ${ }^{1}$ \\ ${ }^{1}$ Department of Internal Medicine III, Cardiology, Angiology, and Pulmonology, University Hospital of Heidelberg, \\ Im Neuenheimer Feld 410, 69120 Heidelberg, Germany \\ ${ }^{2}$ Department of Cancer Biology and Genetics, Memorial Sloan Kettering Cancer Center, 1275 York Avenue, New York, NY 10065, USA
}

Correspondence should be addressed to G. Korosoglou; gkorosoglou@hotmail.com

Received 7 August 2014; Accepted 12 November 2014; Published 27 November 2014

Academic Editor: William J. Brady

Copyright (C) 2014 D. Laohachewin et al. This is an open access article distributed under the Creative Commons Attribution License, which permits unrestricted use, distribution, and reproduction in any medium, provided the original work is properly cited.

\begin{abstract}
Tumour embolisms are rare and in most cases sudden causes of death. Diagnosing this rare condition is still very challenging in the daily clinical routine. In this report we present a case of a lethal sudden pulmonary tumour embolism in a 71-year-old male patient, who was admitted for elective invasive coronary angiography due to suspected coronary artery disease. The patient had suspected Ormond's disease and no previous history of tumour burden. Possible diagnostic and treatment options are discussed herein and an overview of the current literature is also presented.
\end{abstract}

\section{Introduction}

Pulmonary tumour embolisms are a rare and in most cases sudden cause of death. First described in 1897 by Schmidt [1], many patients present with unspecific symptoms and unknown primary tumours. So far, only reviews of case series have been reported, and a large percentage of such patients end with lethal complications. The pathophysiology is currently not entirely understood [2]. In this regard, rapid and effective diagnostic and appropriate treatment strategies are a challenge for clinicians who treat such patients. In recent review articles, several diagnostic algorithms have been discussed. Such algorithms, however, have been developed for the diagnostic work-up of thrombotic embolisms and are therefore not always helpful in patients with carcinoma associated embolisms [2,3]. In this context, it is not surprising that fibrinolytic therapy has been unsuccessful in such cases [4]. Herein, we present a case of tumour associated embolism in a patient with suspected Ormond's disease.

\section{Case Presentation}

A 71-year-old patient was admitted to our department for elective coronary angiography due to suspected coronary artery disease. His main complaint was typical angina at moderate exertion (CCS class II). Additionally, he reported swelling in the scrotum and his right leg during the past 6 months. A deep vein thrombosis was ruled out by negative Doppler sonography. A computed tomography (CT) scan on the other hand showed diffuse proliferation of fibrous tissue in the retroperitoneum, compatible with Ormond's disease (Figure 1). Endoscopic evaluation demonstrated mild gastritis and duodenitis, without further malignant findings. Transthoracic echocardiography revealed preserved left ventricular function and a borderline increase of systolic pulmonary arterial pressure of $35 \mathrm{mmHg}$. Coronary angiography on the other hand revealed a 2-vessel coronary artery disease, with a $50 \%$ stenosis of the left main and mid right coronary artery. In this regard, absence of inducible myocardial ischemia was observed using cardiac dobutamine stress magnetic resonance tomography, and therefore PCI was not performed. In addition, a mild dilatation of the RV was noticed with baseline CMR images. During his hospital stay, however, the patient was found unconscious, centralized, and with apnoea, requiring immediate cardiopulmonary resuscitation and admission to our intensive care unit. Echocardiographic examinations revealed akinetic ventricles without pericardial effusion and ECG showed pulseless electrical 


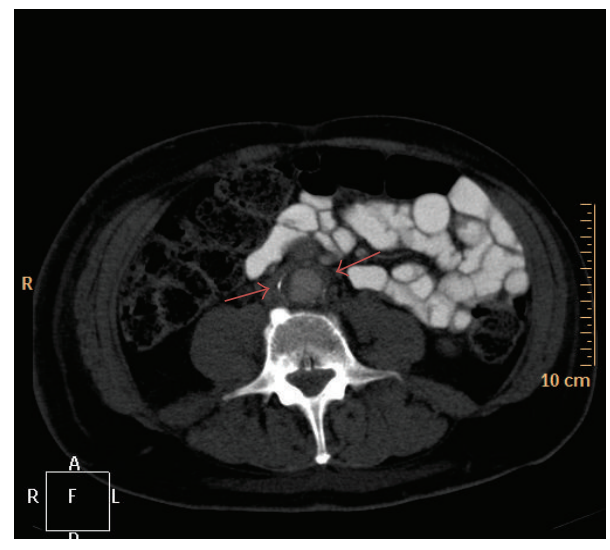

FIgURE 1: Abdominal CT scan illustrating fibrotic, possibly infiltrative changes around the abdominal aorta (red arrows).

activity. The patient expired despite prolonged resuscitation. Postmortem autopsy revealed an unexpected diagnosis. Thus, histopathologic work-up showed a squamous cell carcinoma of the right ureter (apT4, apN3, apM1, V1, G2), which infiltrated the pelvis, corresponding vessels, and periurethral tissue and caused metastatic lesions in the vertebral body (Figures 2(a)-2(c)). In addition, massive embolization of cell conglomerates was observed in the pulmonary vessels causing haemorrhagic infarction of the pulmonary parenchyma (Figure 2(d)).

\section{Discussion}

Pulmonary tumour embolisms remain a rare and in most cases sudden cause of death. Unspecific presentation in symptoms of usually previously unknown primary tumours can prevent both diagnosis and effective treatment [2]. Possible hypotheses explaining massive tumour cell embolization include infiltration of the veins with tumour cells, which subsequently enter the circulation causing embolism of the pulmonary arteries. Once such neoplastic cells have entered the pulmonary circulation, they may additionally induce the activation of the coagulation cascade. Therefore, an admixture of thrombus and tumour cells is usually present in such cases. In recent autopsy series, breast and liver tumours were associated with intravascular tumour, while cases of stomach, prostate, and lung carcinoma demonstrated such a mixed pattern [5]. In addition to such intravascular obstructive mechanisms, mural changes resulting in pulmonary hypertension have also been described. Such mechanisms include medial hypertrophy of small arteries and arterioles, fibrointimal proliferation, intimal fibrosis, and disruption of the internal elastic lamina with endarteritis [5]. In contrast to the classical thromboembolic disease, such proliferative and fibrotic changes usually lead to complete and irreversible occlusion $[2,3,5]$. This may explain why "cor pulmonale" tends to develop earlier and right heart failure symptoms tend to be more severe with tumour embolism
[4-6]. Table 1 gives an overview of so far reported tumourrelated cases of pulmonary embolism (see references listed separately in Supplementary Material available online at http://dx.doi.org/10.1155/2014/396832).

Of course the diagnostic work-up of such cases is challenging for the clinician, since no blood tests or imaging modalities are available for diagnosis. Thus, conventional clinical probability scores [7] would have computed a score of 0 in our case, indicating a very low risk for pulmonary embolism. In addition, standardized blood tests such as measurement of D-dimers [8] probably have low positive and negative predictive value, because baseline tumour activity may lead to false positive and the absence of thrombotic debris within the emboli to false negative results [4]. Plain chest radiographs may be diagnostic in some cases if parenchymal abnormalities, such as fibrotic changes of the lungs, are present [2]. In a case series by Kane et al., however, only one of eight patients has exhibited such parenchymal abnormalities [9]. Computer tomography, on the other hand, has been used in only one study, where "multifocal dilatation and beading of peripheral pulmonary arteries" has been described in 3 cases of pulmonary tumour embolisms [10]. The utility of ventilation/perfusion scans to detect symmetric and peripherally localized defects has also been described [11-13]. Pulmonary angiography, which is still considered as the invasive reference standard technique for the diagnosis of thrombotic embolism, exhibits low sensitivity for the detection of tumour embolisms $[14,15]$. Aspiration cytology has also been discussed as a diagnostic alternative but may be difficult to implement in most cases $[16,17]$.

From a therapeutic point of view, fibrinolytic treatment seems ineffective. One case report has attempted this approach, without ultimate success [4]. As presented in Table 1, some cases, notably atrial myxoma and kidney tumours, have survived due to immediate emergency surgery, which may be a promising alternative in haemodynamic stable patients.

In our case, we followed standard procedures of cardiopulmonary resuscitation [18]. However, our patient unfortunately expired before any diagnosis could be made. Retrospective review of echocardiographic and CMR findings of a borderline increase in pulmonary arterial pressure and mild RV dilatation may had been indicative of previous subclinical embolic events. Even though the definitive diagnosis of our case was set postmortem, having been aware of such pathologic findings beforehand would not have much changed our strategy. An interesting aspect of our case was the additional finding of retroperitoneal fibrotic changes on CT indicative of Ormond's disease. However, retrospective histopathologic work-up showed that these changes were probably related to infiltrative activity of the squamous cell carcinoma, which infiltrated the ureteral wall, periurethral tissue, and probably also the abdominal aorta.

Pulmonary tumour embolisms continue to be clinically challenging in modern medicine. Patient presentation is unspecific and diagnostic options and therapy possibilities remain limited. Further studies are required to establish effective detection and treatment strategies. 
TABLE 1: Overview of reported pulmonary tumour embolisms.

\begin{tabular}{|c|c|c|c|c|c|c|}
\hline Malignancy & $n$ & Chief complaint & $n$ & In-hospital mortality & Diagnostic methods used & $n$ \\
\hline Atrial myxoma & 9 & $\begin{array}{l}\text { Chest pain } \\
\text { Cough } \\
\text { Dyspnea } \\
\text { Fever } \\
\text { Shock }\end{array}$ & $\begin{array}{l}1 \\
1 \\
7 \\
1 \\
1\end{array}$ & $33,30 \%$ & $\begin{array}{l}\text { Autopsy } \\
\text { CT } \\
\text { Surgery } \\
\text { PET/CT }\end{array}$ & $\begin{array}{l}2 \\
6 \\
6 \\
1\end{array}$ \\
\hline Bladder & 4 & $\begin{array}{l}\text { Chest pain } \\
\text { Dyspnea } \\
\text { None } \\
\end{array}$ & $\begin{array}{l}1 \\
2 \\
1\end{array}$ & $100 \%$ & $\begin{array}{c}\text { Autopsy } \\
\text { Pulmonary angiogram }\end{array}$ & $\begin{array}{l}4 \\
1\end{array}$ \\
\hline Breast & 30 & $\begin{array}{l}\text { Chest pain } \\
\text { Dyspnea } \\
\text { None }\end{array}$ & $\begin{array}{c}2 \\
28 \\
2\end{array}$ & $93,30 \%$ & $\begin{array}{c}\text { Autopsy } \\
\text { Pulmonary angiogram } \\
\text { Aspiration cytology } \\
\text { Radio nuclear perfusion } \\
\text { Surgery } \\
\text { Ventilation/perfusion scan }\end{array}$ & $\begin{array}{r}27 \\
4 \\
1 \\
3 \\
1 \\
3\end{array}$ \\
\hline Colon & 5 & $\begin{array}{l}\text { Abdominal pain } \\
\text { Cough } \\
\text { Dyspnea } \\
\text { Fever } \\
\text { None } \\
\end{array}$ & $\begin{array}{l}1 \\
1 \\
2 \\
1 \\
1\end{array}$ & $100 \%$ & Autopsy & 5 \\
\hline Kidney & 10 & $\begin{array}{l}\text { Chest pain } \\
\text { Dyspnea } \\
\text { None } \\
\text { Shock } \\
\end{array}$ & $\begin{array}{l}1 \\
8 \\
1 \\
1\end{array}$ & $30 \%$ & $\begin{array}{l}\text { Autopsy } \\
\text { CT } \\
\text { Surgery }\end{array}$ & $\begin{array}{l}1 \\
8 \\
8\end{array}$ \\
\hline Liver & 9 & $\begin{array}{c}\text { Chest pain } \\
\text { Dyspnea } \\
\text { Fever } \\
\text { None } \\
\end{array}$ & $\begin{array}{l}2 \\
5 \\
1 \\
2 \\
\end{array}$ & $88,90 \%$ & $\begin{array}{c}\text { Autopsy } \\
\text { Pulmonary angiogram } \\
\text { CT } \\
\text { Aspiration cytology }\end{array}$ & $\begin{array}{l}8 \\
2 \\
2 \\
1 \\
\end{array}$ \\
\hline Lung & 12 & $\begin{array}{l}\text { Cough } \\
\text { Dyspnea } \\
\text { None } \\
\text { Shock }\end{array}$ & $\begin{array}{l}1 \\
9 \\
1 \\
1\end{array}$ & $91,70 \%$ & $\begin{array}{c}\text { Autopsy } \\
\text { Pulmonary angiogram } \\
\text { CT } \\
\text { Radio nuclear perfusion } \\
\text { Surgery } \\
\text { Ventilation/perfusion scan }\end{array}$ & $\begin{array}{c}11 \\
1 \\
2 \\
1 \\
1 \\
2\end{array}$ \\
\hline Oesophagus & 4 & Dyspnea & 4 & $100 \%$ & Autopsy & 4 \\
\hline Pancreas & 6 & $\begin{array}{l}\text { Dyspnea } \\
\text { Fever } \\
\text { None }\end{array}$ & $\begin{array}{l}4 \\
1 \\
2\end{array}$ & $83,30 \%$ & $\begin{array}{c}\text { Autopsy } \\
\text { EUS } \\
\text { Ventilation/perfusion scan }\end{array}$ & $\begin{array}{l}5 \\
1 \\
2 \\
\end{array}$ \\
\hline Prostate & 4 & $\begin{array}{c}\text { Dyspnea } \\
\text { None }\end{array}$ & $\begin{array}{l}3 \\
1 \\
\end{array}$ & $83,30 \%$ & Autopsy & 4 \\
\hline Stomach & 38 & $\begin{array}{l}\text { Cough } \\
\text { Dyspnea } \\
\text { Fever } \\
\text { None }\end{array}$ & $\begin{array}{c}1 \\
32 \\
1 \\
5\end{array}$ & $100 \%$ & $\begin{array}{c}\text { Autopsy } \\
\text { Pulmonary angiogram } \\
\text { CT } \\
\text { Aspiration cytology } \\
\text { Ventilation/perfusion scan }\end{array}$ & $\begin{array}{c}37 \\
1 \\
2 \\
1 \\
3\end{array}$ \\
\hline Wilms' tumour & 6 & $\begin{array}{c}\text { Abdominal pain } \\
\text { Diffuse } \\
\text { Dyspnea } \\
\end{array}$ & $\begin{array}{l}1 \\
4 \\
2\end{array}$ & $83,30 \%$ & $\begin{array}{c}\text { Autopsy } \\
\text { CT } \\
\text { Ventilation/perfusion scan }\end{array}$ & $\begin{array}{l}5 \\
1 \\
1 \\
\end{array}$ \\
\hline Others ${ }^{*}$ & 38 & $\begin{array}{l}\text { Chest pain } \\
\text { Cough } \\
\text { Dyspnea } \\
\text { Fever } \\
\text { None } \\
\text { Shock }\end{array}$ & $\begin{array}{c}3 \\
2 \\
31 \\
2 \\
1 \\
1\end{array}$ & $52,60 \%$ & $\begin{array}{c}\text { Autopsy } \\
\text { Pulmonary angiogram } \\
\text { CT } \\
\text { Aspiration cytology } \\
\text { Radio nuclear perfusion } \\
\text { EUS } \\
\text { Surgery } \\
\text { Ventilation/perfusion scan }\end{array}$ & $\begin{array}{c}16 \\
2 \\
19 \\
1 \\
4 \\
1 \\
12 \\
5\end{array}$ \\
\hline
\end{tabular}

* Others include bile duct, bone, leukemia, lymphoma, cartilage, cervix, choriocarcinoma, epidural, Ewing, fibroelastoma, glioblastoma, cardiac leiomyomatosis, multiple myeloma, ovary, parotid gland, sphenoid sinus, testis, thyroid, synovial sarcoma, unknown, and uterus. 


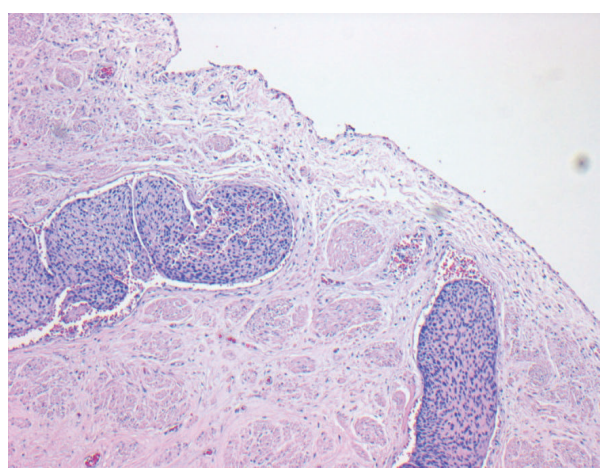

(a)

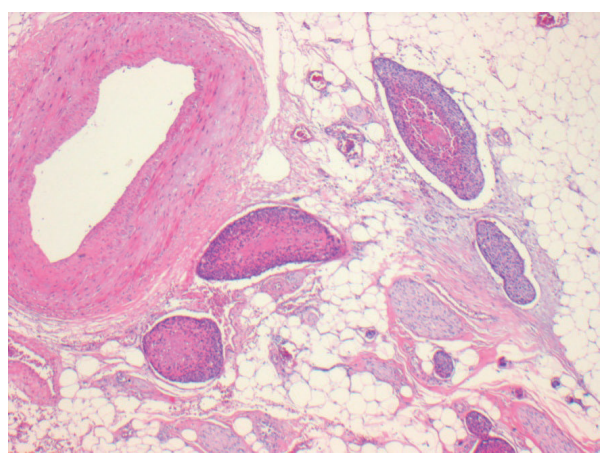

(c)

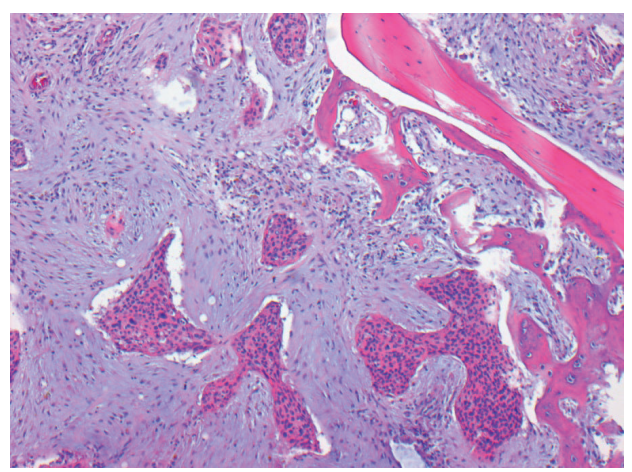

(b)

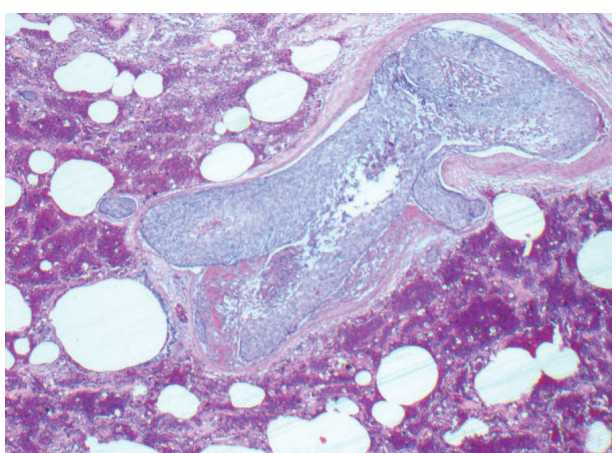

(d)

Figure 2: (a) Squamous cell carcinoma manifestation in the ureteral wall. (b) Metastatic manifestation of the squamous cell carcinoma lesion in the vertebral body. (c) Tumour infiltration of periurethral fat tissue. (d) Pulmonary vessels with extensive squamous cell carcinoma tumour embolisms and haemorrhagic infarction of the pulmonary parenchyma.

\section{Conflict of Interests}

The authors declare that they have no conflict of interests.

\section{References}

[1] M. B. Schmidt, Die Verbreitungswege der Karzinome und die Beziehung generalisierter Sarkome zu den leukämischen Neubildungen, Fischer, 1903.

[2] K. E. Roberts, D. Hamele-Bena, A. Saqi, C. A. Stein, and R. P. Cole, "Pulmonary tumor embolism: a review of the literature," The American Journal of Medicine, vol. 115, no. 3, pp. 228-232, 2003.

[3] D. J. Shields and W. D. Edwards, "Pulmonary hypertension attributable to neoplastic emboli: an autopsy study of 20 cases and a review of literature," Cardiovascular Pathology, vol. 1, no. 4, pp. 279-287, 1992.

[4] A. Rüchardt, B. Gruber, and P. Trenkwalder, "Intrapulmonary tumour cell embolism from cancer of the bladder as cause of a subacute cor pulmonale," Deutsche Medizinische Wochenschrift, vol. 126, no. 30, pp. 847-850, 2001.

[5] A. G. Bassiri, B. Haghighi, R. L. Doyle, G. J. Berry, and N. W. Rizk, "Pulmonary tumor embolism," American Journal of Respiratory and Critical Care Medicine, vol. 155, no. 6, pp. 20892095, 1997.

[6] W. R. Owen, W. A. Thomas, B. Castleman, and E. F. Bland, "Unrecognized emboli to the lungs with subsequent cor pulmonale," The New England Journal of Medicine, vol. 249, no. 23, pp. 919-926, 1953.
[7] P. S. Wells, D. R. Anderson, M. Rodger et al., "Derivation of a simple clinical model to categorize patients probability of pulmonary embolism: increasing the models utility with the SimpliRED D-dimer," Thrombosis and Haemostasis, vol. 83, no. 3, pp. 416-420, 2000.

[8] A. Torbicki, A. Perrier, S. Konstantinides et al., "Guidelines on the diagnosis and management of acute pulmonary embolism: the Task Force for the Diagnosis and Management of Acute Pulmonary Embolism of the European Society of Cardiology (ESC)," European Heart Journal, vol. 29, no. 18, pp. 2276-2315, 2008.

[9] R. D. Kane, H. K. Hawkins, J. A. Miller, and P. S. Noce, "Microscopic pulmonary tumor emboli associated with dyspnea," Cancer, vol. 36, no. 4, pp. 1473-1482, 1975.

[10] J.-A. O. Shepard, E. H. Moore, P. A. Templeton, and T. C. McLoud, "Pulmonary intravascular tumor emboli: dilated and beaded peripheral pulmonary arteries at CT," Radiology, vol. 187, no. 3, pp. 797-801, 1993.

[11] W. L. Chen, S. C. Cherng, W. S. Hwang, D. J. Wang, and J. Wei, "Perfusion scan in pulmonary tumor microembolism: report of a case," Journal of the Formosan Medical Association, vol. 90, no. 9, pp. 863-866, 1991.

[12] H. D. Sostman, M. Brown, A. Toole, S. Bobrow, and A. Gottschalk, "Perfusion scan in pulmonary vascular/lymphangitic carcinomatosis: the segmental contour pattern," The American Journal of Roentgenology, vol. 137, no. 5, pp. 1072-1074, 1981.

[13] R. Crane, T. G. Rudd, and D. Dail, "Tumor microembolism: pulmonary perfusion pattern," Journal of Nuclear Medicine, vol. 25 , no. 8 , pp. $877-880,1984$. 
[14] R. W. Schriner, J. H. Ryu, and W. D. Edwards, "Microscopic pulmonary tumor embolism causing subacute cor pulmonale: a difficult antemortem diagnosis," Mayo Clinic Proceedings, vol. 66, no. 2, pp. 143-148, 1991.

[15] M. Hibbert and S. Braude, “Tumour microembolism presenting as "primary pulmonary hypertension"'” Thorax, vol. 52, no. 11, pp. 1016-1017, 1997.

[16] J. S. Bhuvaneswaran, C. G. Venkitachalam, and S. Sandhyamani, "Pulmonary wedge aspiration cytology in the diagnosis of recurrent tumour embolism causing pulmonary arterial hypertension," International Journal of Cardiology, vol. 39, no. 3, pp. 209-212, 1993.

[17] J. M. Shapiro, D. E. Avigan, M. K. Warshofsky, E. Greenebaum, and R. P. Cole, "Acute cor pulmonale due to tumor emboli. Diagnosis by pulmonary artery catheterization," New York State Journal of Medicine, vol. 93, no. 3, pp. 197-198, 1993.

[18] A. J. Handley, R. Koster, K. Monsieurs, G. D. Perkins, S. Davies, and L. Bossaert, "European Resuscitation Council Guidelines for Resuscitation 2005: section 2. Adult basic life support and use of automated external defibrillators," Resuscitation, vol. 67, no. 1, pp. S7-S23, 2005. 


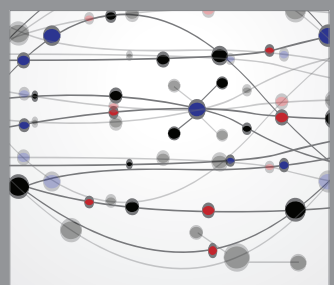

The Scientific World Journal
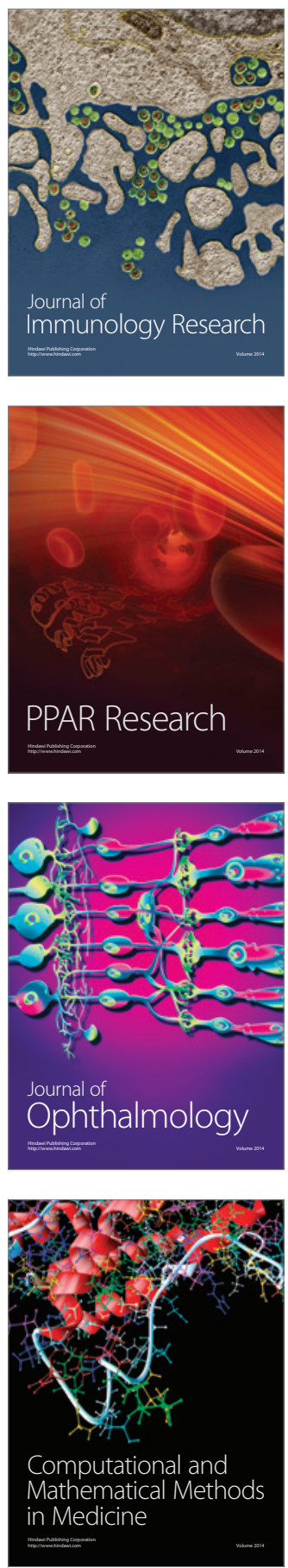

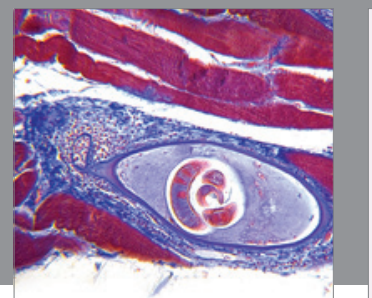

Gastroenterology

Research and Practice
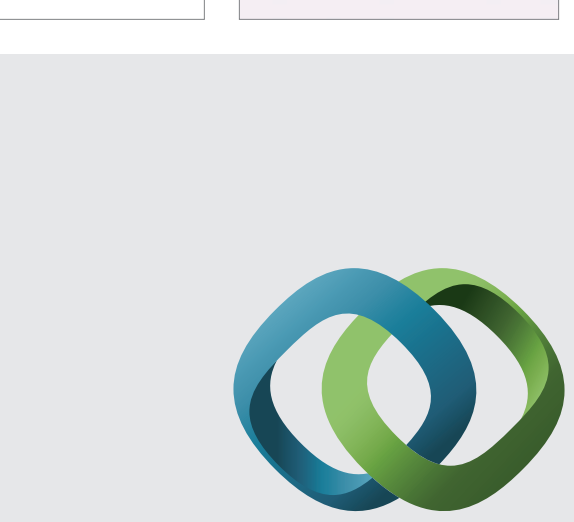

\section{Hindawi}

Submit your manuscripts at

http://www.hindawi.com
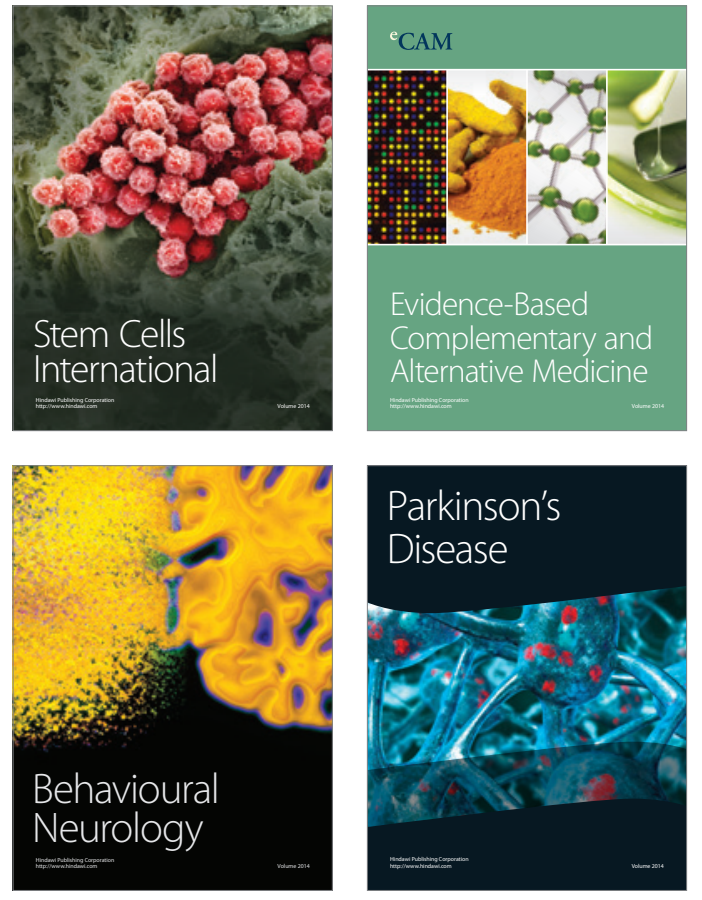
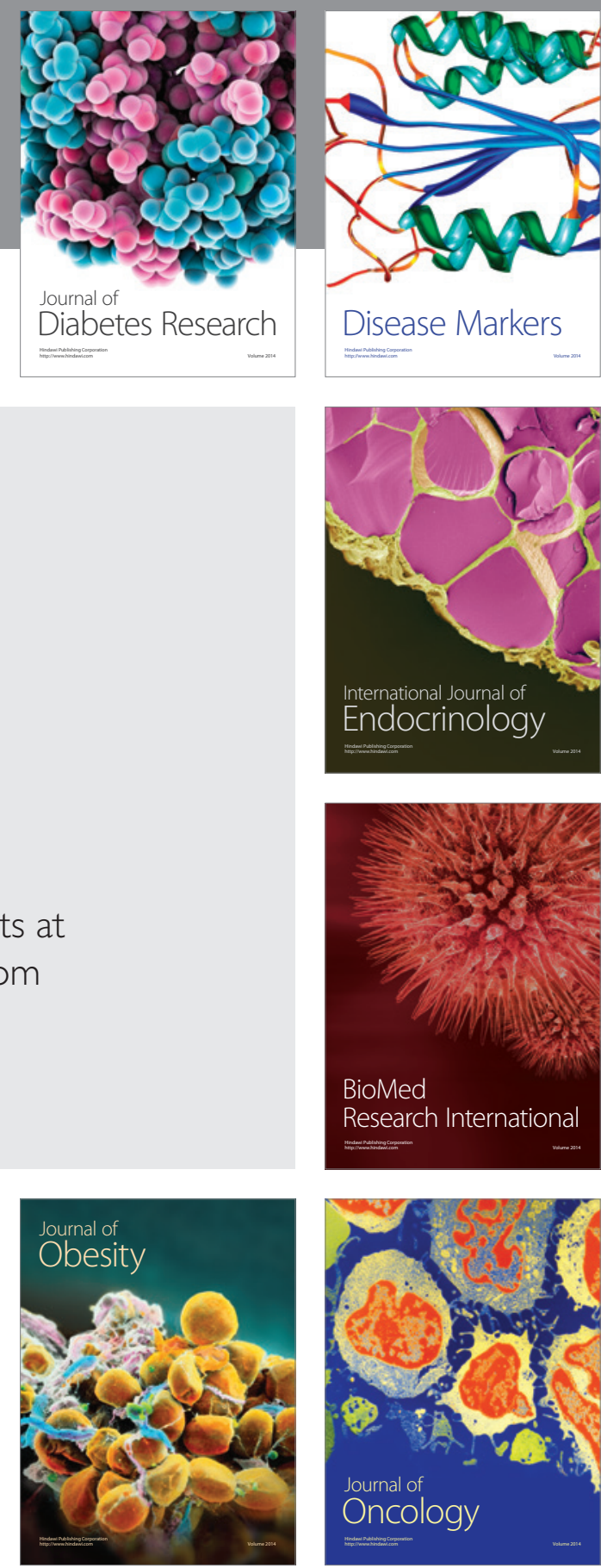

Disease Markers
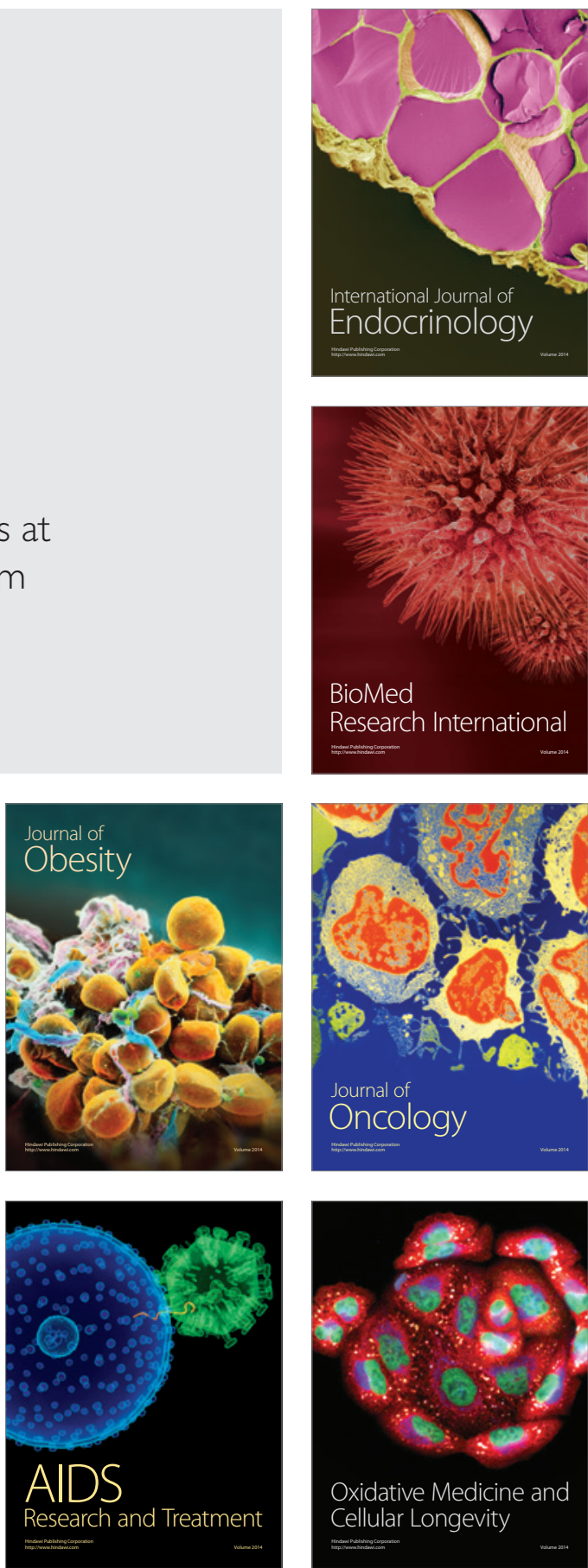